\title{
The Study of Assessing the Impact on Environment by the Noxious Airborne Chemicals: a Review
}

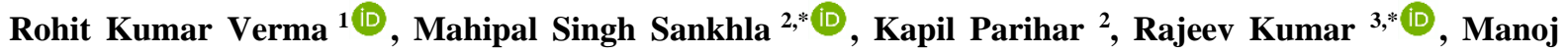 \\ Kumar Verma 4 (iD \\ 1 Dr. APJ Abdul Kalam Institute of Forensic Science \& Criminology, Bundelkhand University, Jhansi, India; \\ rohitlyn8423@gmail.com (R.K.V.); \\ 2 Department of Forensic Science, School of Basic and Applied Sciences, Galgotias University, Greater Noida, India; \\ mahipa14n6@gmail.com (M.S.S.); \\ 3 Department of Forensic Science, School of Basic and Applied Sciences, Galgotias University, Greater Noida, India; \\ rajeev4n6@gmail.com (R.K.); \\ 4 Chemistry Division, State Forensic Science Laboratory, Lucknow; manojchemlu@ gmail.com (M.K.V.); \\ * Correspondence: mahipal4n6@gmail.com;
}

Received: 1.10.2020; Revised: 4.11.2020; Accepted: 9.11.2020; Published: 15.11.2020

\begin{abstract}
In the current scenario, hazardous airborne chemicals are spreading all over the world. These can be found in the form of gases, vapors, particulate matters, or solid. Some of the airborne elements similar cadmium, lead, arsenic, zinc, mercury, fluoride, chromium, nickel, copper, manganese, etc. and approximately the hazardous airborne gases are carbon monoxide, hydrogen sulfide, nitrogen oxides, methane, ammonia, nitrogen dioxide, sulfur dioxide, etc. which are very poisonous to the environment and for human health. The major source of airborne chemicals in factories, industries, mining activities, agricultural activities, motor vehicles, burning of fossil fuels, indoor air pollution, etc. which release the very harmful gases and elements by which the air get polluted and by this intake of polluted airborne chemicals, humans are suffering from the various disease like cancer birth defects and respiratory diseases, etc., death may also occur. This review explains the detailed study of hazardous airborne gases and toxic chemicals.
\end{abstract}

Keywords: airborne; chemicals; environment; toxic; respiratory diseases.

(C) 2020 by the authors. This article is an open-access article distributed under the terms and conditions of the Creative Commons Attribution (CC BY) license (https://creativecommons.org/licenses/by/4.0/).

\section{Introduction}

Airborne chemicals are exogenous constituents in enclosed or outside airborne, containing together particulates and gaseous chemicals that might cause opposing well-being special effects in humans or animals, distress vegetable lifetime, and influence the worldwide surroundings by altering the air of the world [1]. Airborne particulate substance, which is selfpossessed of a wide session of chemically and substantially varied constituents, is variable in proportions, biochemical structure, development, source, and absorption. It is mutable through space and period. Fitness special effects related to particulate matter (PM) are connected to respirational, cardiac difficulties, and early humanity [2]. Approximately, the chemicals will come in the form over the skin and approximately through the airlines. So, the assessment of acquaintance might be achieved together by airborne and dermal measurements [3]. Metallic chemicals are released into the air from many causes containing incineration of fossil fuels, metal smelters, alloy factories, industrial cement plants, and public furnaces. Metals and metallic mixtures occur in the air in three different physical methods: solid particulate substance, fluid dewdrops (vapors), and fumes. The wide variety of airborne particulates 
material stays wide [4]. Toxic components happen in exact minor amounts in the world's coating (less than $1000 \mathrm{ppm}$ ) and later named trace metals. These are additional randomly subdivided at the beginning of their concentrations; those taking thicknesses underneath $5 \mathrm{~g} \mathrm{~cm}-3$ are named 'light metals', and individuals with densities beyond $5 \mathrm{~g} \mathrm{~cm}^{-3}$ are entitled as 'heavy metals'. Therefore, metals similar $\mathrm{Pb}, \mathrm{Cu}, \mathrm{Zn}$, and $\mathrm{Ni}$, etc., are usually 'well-known as poisonous heavy metals'. Below this classification, the commonly measured amazingly also even metalloids, As and Sb, thus creating it as if the word 'heavy metals' is a contradiction. Though the poisonous heavy metals are current in the world's top in trace heights, anthropogenic doings such as industrial processing and usage of metals, blends, and metallic mixtures scatter them into the surroundings, therefore adding up and about to their normal circumstantial stages [5.6]. Numerous earlier studies have recognized the airborne focusses on numerous metallic components in the reduction. Others have also made an effort to estimate the associated atmospheric loading. This pointed out the difficulties encountered in quantifying different modes of atmospheric inputs, i.e., wet, dry, and total inputs. [7] have reported. Though several metals are normal tissue constituents, metals such as arsenic, antimony, lead, cadmium, mercury, and bismuth are identified to be poisonous even at small points. On behalf of the earlier few periods, eminent altitudes of metals and their composites, both inorganic and organic, have been out to the environments an outcome of various anthropogenic activities. The main sources of heavy metals contain numerous industrialized causes such as mining activities, foundries and smelters, and diffuse causes such as ignition, traffic, and tubing [8]. In India, owing to growing road traffic, unintended urban and industrial enlargement, increasing vigor ingestion, and the high invasion of inhabitants to municipal areas, disturbing stages of particulate substance are stated in city exospheres [9]. Furthermore, cumulative the amount of available manufacturing substances and new goods has produced a claim for substitutes to animal approaches for a healthier care assessment. Though learning the poisonous special effects of gasped compounds is strictly stimulating, the possible request of in vitro approaches to education, the poisonousness of airborne chemicals desires to be occupied into thought [10]. Unintentional discharges of dangerous constituents signify one-of the supreme problematic features of hazardous resources organization. Thousands of companies in the United States grip poisonous constituents, consequently an unintended discharge can happen virtually wherever: at the industrial unit or granary, on streets or railways, or in canals. Approximately 12000 transport accidents concerning dangerous constituents happen annually; perchance as numerous as 3 to 4 times as several go unreported [11]. An airborne particulate substance with an aerodynamic diameter of do7:2 mm (PM7.2) was composed throughout the era seasonal 1997-summer 1998 at six places in the better part of Thessaloniki, N. Greece, also wedged by municipal or by industrialized accomplishments. Chief urban accomplishments in part are automobile road traffic through the year and inhabited warming by mainly purified oil in the course of wintertime. Main industrialized doings are oil refining, petrochemical, fertilizer production, non-ferrous metal smelting, iron and steel manufacturing, electrolytic $\mathrm{MnO} 2$ construction, scrap metal incineration, truck, and auto painting, etc. [12]. The chief contamination cause in the education extent is owing to numerous harmful gases and particulate releases after open cast mines, coal-based productions. Diesel established vehicular movement in tow infrastructures, freeing huge quantities of contaminants into the air, coal washers, and growing vehicular populace (weighty and light duty). Separately since this, through the outline of new mining skills, which provides original machines and methods in the coal removal subdivisions to improve contamination [13], the Nursing of ambient air excellence is the 
primary stage to checked the position of contamination in the slight region of curiosity. These waste masses are causes of air contaminants that contain satisfactory particulate substance (PM2.5), volatile organic compounds (VOCs), nitrogen oxides (NOx), and owing to inadequate incineration carbon monoxide (CO) and polycyclic aromatic hydrocarbons (PAHs), several of which the International Agency for Research on Cancer (IARC) lists as likely cancer-causing agent. Additionally, waste burning might donate to the establishment of atmospheric brown vapors; meanwhile, educations have known that extra burning observes (e.g., agricultural burning, household biomass burning) are vital suppliers [14.15]. The essential data on airborne chemicals can be gained by dispersal demonstrating (source-orientation, a priori identified radiation causes) and arena dimensions of the emission (receptor/effect orientation). In several nations, spreading demonstrating has increased more and more attention, also created on financial details: practical field dimensions need apparatus and human resources and are usually connected with maximum rates $[16,17]$. Particulate air contamination has remained the emphasis of a worldwide investigation exertion for numerous years. The purposes have remained not to recognize and define relations amid acquaintance and ability to harmfully affect human fitness, then too to classify the reasonable organic contrivances that might clarify and provision these relations [18]. Though the breathing organs are the main goal place for the poisonous special effects of airborne micro(nano)plastics, the slight investigation has absorbed the breath noxiousness of micro(nano)plastics. Greatest micro(nano)plastic noxiousness studies have used in vitro tests or oral admin [19,20]. This proposes that while AO's consequence at the separate level has not remained established in the immunostaining consequences, the poisonous outcome at the molecular level can occur adequately. These molecular-level effects can main to AO contingent on contact concentration and circumstances. In addition, TGF-b and TNF-a are indicators comprised of the AOP of pulmonary fibrosis established in our earlier studies, which increases the opportunity that micro(nano)plastics can persuade pulmonary fibrosis [21]. Airborne particulate matter (PM) is a contaminant of anxiety not only since of its opposing special effects on human well-being but since of its capability to decrease discernibility and soil structures and resources. It can be observed as a set of contaminants; meanwhile, PM covers a very varied series of particle sizes and has a varied biochemical structure. In history, an abundance of the PM arose from coal-burning and was dignified as black smoke. In the other half of the twentieth century in established nations, there was a reduction in black smoke releases from coal-burning and PM steadily established conquered by carbonaceous elements from road traffic use and the secondary pollutants ammonium salts and secondary organic carbon. This is demonstrated by the structure of fine particles (referred to as PM2.5) as measured in London, Delhi, and Beijing. Gradually, as control plans have given a lecture, the more docile causes of emissions, so sources before stared as an alternative have occurred and have remained seen to brand an important influence to airborne PM concentrations [22]. Firstly, the light-duty vehicle fleet in Beijing is wholly gasoline-fuelled, which leads to much lower emissions of particles than diesel, which contributes a large part of the light-duty fleet in London. In London, heavy-duty vehicles can move within the city at all times of day and night. In contrast, in Beijing, the heavy-duty vehicles are restricted to the nighttime hours. Beijing's early afternoon peak is almost certainly the result of new particle formation through regional nucleation processes referred to later in this article [23]. It is the decrease in the corpus callosum volume during gestation [24]. There have been major reductions in VOC emissions in the UK over the past decades. However, it is unclear whether these have been reflected in a reduction of anthropogenic secondary aerosol. 
The biogenic ancestors are recognized to type an important influence. There appears a slight view of these reducing in the near future. It appears that non-traffic related VOC arising from domestic emissions of solvents and personal care products now contribute substantially to secondary organic aerosol [25].

\section{Principles of toxic airborne chemicals}

The performance of chemicals in the surroundings, i.e., from the basis via conveyance to the aim (organisms, ecosystems but also structures or buildings) is the main theme which traces various influences from physics of transference and supply to biochemical responses and the part of microorganisms in the break of organic chemicals. It delivers a brief yet a new or less whole list of contamination causes and transportation mass media, comprising warfare, industrialized accidents (Bhopal, Seveso, etc.), an organization of dangerous materials, and a "red list" of chemicals in some countries [26]. This principle must be obvious to the point that one would remain uncomfortable with a smooth discussion. The truth is that millions of Europeans live in parts where it is insecure about respiring the air about them. It identifies the desire to reduce airborne chemicals to heights, diminishing injurious special effects on human health. The limited value assumed for airborne particulate substance was far advanced than suggested by the World Health Organization (WHO). For instance, a yearly regular limited worth for respirable elements (particulate matter with a 50\% cut-off aerodynamic diameter of $2.5 \mathrm{~mm}$; PM2.5) as usual at $25 \mathrm{mg} / \mathrm{m}^{-3}$, which is 2.5 times advanced other than the equal suggested by the WHO. WHO rules are constructed on healthiness deliberations only and do not explain the efficient otherwise mechanical viability of the conference the strategies. The EU Instruction knows that there is no recognizable verge for PM2.5 and conditions that would object to over-all decreases in absorptions at urban circumstantial places. Though, no required judicial events take stayed occupied so distant to apply this. A complete valuation of the community fitness features of the present instruction has existed issued [27].

\section{Major sources of toxic airborne chemicals}

\subsection{Anthropogenic source.}

Iron, zinc, lead, vanadium, manganese, chromium, copper, nickel, arsenic, cobalt, cadmium, antimony, and mercury are the most important trace essentials frequently establish in supreme kinds of fired coal influence plant residue remain, in declining demand of concentration. Several of these components are described to be improved in the premium elements aimed at which particulate controller strategies are smallest in effect. For instance, an examination of together reserved and released fly residue from a fired-coal producing position armed with a cyclonic precipitation arrangement specified distinct enhancement of the types: zinc, arsenic, lead, chromium, nickel, antimony, and cadmium. Inadequate enhancement was originated for iron, manganese, and vanadium and no enhancement for copper, tin, and cobalt. That one remained assumed by these other agents that convinced essentials (i.e., with boiling points below the temperature of coal incineration) are volatilized and might also adsorb or shorten onto entrained elements with extreme form per unit weight for the least elements. Oilfired thermal producing station fly ash has been present. It includes vanadium, iron, zinc, lead, copper, arsenic, cobalt, chromium, manganese, and antimony. Ignition of public waste is an additional possible cause of the trace components zinc, iron, mercury, and lead with lesser quantities of tin, arsenic, cadmium, cobalt, copper, manganese, nickel, and antimony, reliant 
on the food kind. Primarily iron and some zinc, with lesser amounts of chromium, copper, manganese, nickel, and lead, are contributed in Open-hearth incinerators in steel mills. Release data, measured in the plume of the main nickel smelter, specify the principally produced components iron, copper, and nickel were mostly connected with rough particle sizes. However, lead, zinc, and cadmium, present in smaller quantities, were mainly connected with the fine elemental form. Productions of vehicles burning steady gasoline comprise lead with lesser quantities of zinc and iron. As well-known formerly, lesser elements resulting from great temperature ignition procedures likely to be enriched with poisonous trace components such as arsenic, cadmium, chromium, lead, vanadium, and zinc. Consequently, some detectives take well-known suggestions regarding health (i.e., greater pulmonary system penetration) [28].

\subsection{Industrial source.}

Airborne chemicals have developed a main problematic rising mostly from industrial development and suburbanization throughout the previous few years. Particulate matter is excessive apprehension relative to their opposing influence on human well-being and vegetation [29]. The most usually recognized causes are vehicles, industrial and electrical energy generation activities, building undertakings, road dust, waste burning, burning of oil, coal, 154 and biomass in the households, and marine/sea salt. Pune, Chennai, Delhi, Mumbai, Kanpur, and Bengaluru, at an approximate project 156 costs of US\$6 million, are some multicity of which CPCB presented studies for six cities [30]. Industrial emissions are typically diverse, with releases connected with altered industrial methods like petrochemical, metallurgic, ceramic, and pharmaceutical. A sequence of marker species ( $\mathrm{Ni}, \mathrm{Cr}, \mathrm{Co}, \mathrm{Cd}$, and As) has been recycled for particulate SA studies accompanied in India. Moreover, diverse trace essential indications take also been used to classify precise industrialized releases, most particularly $\mathrm{Cu}, \mathrm{Mn}$, and $\mathrm{Ni}$ from ferrous metal processing and steel industries in Mumbai [31]. The third cause recognized originated to be a fusion of incineration and industrial production causes. The previous influence was originated through great loadings of $\mathrm{Br}$, which might be after the near Liquid bromine and sodium bromide developed industries. Likewise, soil, sea salt, combustion, industries, and Se causes have been recognized from the multivariate examination of the fine portion data set. The past four decades have brought to light the role of policies, land-use decisions, regulations, and market-based forces in contributing to social inequalities in residential proximity to industry and resultant exposures to harmful chemicals that disproportionately impact low-income communities of color [32,102]. Due to fast industrial development, urbanization and increasing population disturbingly contaminate the simple properties essential to prolong lifespan. The summary pace of manufacturing and commercial accomplishments in many emerging republics contributed suggestively to an enlarged level of airborne chemicals, enhanced in various poisonous heavy metals. Among the diversity of issues inducing peoples' healthiness, natural elements and artificial ecological changes play a crucial role. Chemical agents that are released into the surroundings from many anthropogenic events influence human health extremely. The respiratory system is one most important ways these chemicals and poisonous causes come into the human body and affect syndromes, comprising impermanence [33]. The past four decades have brought to light the role of policies, land-use decisions, regulations, and market-based forces in contributing to social inequalities in residential proximity to industry and resultant exposures to harmful chemicals that disproportionately impact low-income communities of color [2]. 


\section{Ecological changes in toxic airborne chemicals}

There is several unintended and important consequence of particulate substance on the environment. Unintended plant reactions of extreme attention are mainly soil-mediated. They hinge chiefly on the biochemical arrangement of the distinct components current in particulate substance. Alterations in the dirt might not be detected until the chemical build-up has happened for 10 or extra years, but in the harshly contaminated zones about industrial fact causes [34]. The incidental effect is typically long-lasting and happen over the period and are problematic to define since the variations are delicate [35]. Acquaintance signifies the occasion when an individual derives into interaction with a chemical for a specific period. On the net side, quantity denotes the real number of chemicals that sign a frame's fence. Airborne particulate matter (PM) is the new emphasis of the ecosphere communal as it enters the respiratory system of human existence and sources numerous complaints. In the circumstance of airborne chemicals, it is supposed that flowing mass, amount, and amount of air pollution in the environment show a vigorous character in impacting human fitness. Besides being presented through universal studies, the city populace is in danger owed to raised stages of airborne chemicals in the cities on the surrounding. Some while sequence and cohort educations have presented that kids, elderly and asthmatic persons are at advanced danger owing to air pollution. The study summarizes outside airborne particulates and their influence on the human health effect [36]. Several current studies detected that in built-up stratospheres, the deliberations of PM10 and PM 2.5 air sprays demonstrate decent contracts with trafficrelated toxins and other incineration routes [37]. While, crustal physical, suspended way dirt and long-term transportation proceedings are mostly recognized as causes of the uneven elements $[38,39]$. Vehicles' statements and rural actions produce native dirt concentrations near the cause, surpassing ecological advice standards [40, 41].

\section{Consequences of toxic airborne chemicals}

Unpredictably, $\mathrm{NO}_{2}$ concentrations take been cumulative in numerous parts as a sign of changed $\mathrm{NO}_{2} / \mathrm{NO}_{\mathrm{x}}$ ratios in releases of diesel appliances armed with element traps. Occasionally, short-range top attentions influence hundreds of micrograms per cubic meter. These heights might include goods severe respirational special effects in vulnerable focus. Studies have exposed that the yearly regular maximum worth of $40 \mathrm{mg}$ ? $\mathrm{M}^{-3}$ will be surpassed at numerous wayside sites throughout Europe for years to originate. The fitness hazards associated with long-term usual chemical mixes with such raised $\mathrm{NO}_{2}$ attentions need more study. The relation between $\mathrm{NO}_{2}$ and other constituents of the mix have been altering [42]. The developing problem of air contamination as a consequence of the various developing events in industrialized, transport, and other connected fields in India, is gathering courtesy of the politicians, shareholders, and mutual man. Though many severe steps have previously been taken in India's megacities to tackle the airborne contamination difficult, numerous small cities and towns are static, fronting this problematic $[43,44]$. The current works examination will precise the national information on the proofs of atmospheric pollution with artificial polymers and their determinations and sound effects in plants when breath, especially going on individuals, by deliberating current investigation concerning airborne micro-plastics (for easiness this word will also contain Nano plastics, plastics $<100 \mathrm{~nm}$ that are probably existing in the air and breathe in due to their small proportions). Five divisions report acquaintance and health effects of air-polluted microplastics in the subsequent direction: (1) examination of 
disclosure built on attentions and influences of supply; (2) industrial infections associated to airborne microplastics acquaintance; (3) mechanisms of component poisonousness for airborne microplastics; (4) mechanisms of translocation; (5) other appliances of toxicity besides element toxicity; (6) conversation of significances to the human condition [45].

\section{Hazardous metals found in airborne chemicals}

Several earlier studies have recognized the airborne concentrations of some metal components in the fall. Others have also attempted to estimate the connected atmospheric filling. This keen out the difficulties encountered in quantifying different modes of atmospheric inputs, i.e., wet, dry, and total inputs. [46] have stated that approximately metallic in airborne dust particulates and stated that the total fluxes of $0.18,0.35,6.0,3.7$, and $220 \mu \mathrm{g} \mathrm{m}-2 \mathrm{~d}-1$ total fluxes were dignified for $\mathrm{Cd}, \mathrm{Co}, \mathrm{Cu}, \mathrm{Ni}$, and $\mathrm{Zn}$, respectively. Great heavy metal focusses about Aliage Developed Place in Turkey, particularly close to iron smelters and steel mill cut is described due to industrialized events. Metals such as Zinc, Chromium, Nickel, Cadmium, and mercury, etc., are recognized for poisonous influence on human fitness. The entrance of these essentials into the atmosphere over industrialized or further anthropogenic sources wants to be checked with anxiety cause these components $[47,48]$ have studied the outline into the surroundings of these metallic impurities in developed parts. The absorptions ( $\mathrm{mg} \mathrm{kg}-1)$ of the great number of poisonous components in the dirt fall-out substance deposited from parts of maximum fall-out amounts in the united steel plant's locality have been described as follows: Ni 190.0, Zn 120.0, Cu 50.0, Cr 140.0, and Mn 142.0. Examination on metallic concentration in particulate matter in the ambient air of Steel City, Rourkela, in eastern India has presented marvelous pollution in the air [49]. Environmental contamination from harmful metals and minerals can rise from usual, as well as anthropogenic causes. Outflow from rocks into the water, volcanic activity, forest fires, etc. Contamination too rises after separating of contaminating fundamentals (that are focussed in terracotta raw materials with great absorption abilities), among alluvial rocks and their ancestor residues and liquid. (Sir Sen, personal communication). Through quick industrial development and commercial lifestyle, anthropogenic causes of ecological contamination consume enlarged. The contamination happens together at the equal of industrialized manufacture otherwise close use for the goods then overflow. The poisonous fundamentals come in the human form typically concluded air, food, and water and to a minor level concluded breathing of contaminated airborne, usage of cosmetics, remedies, deprived value herbal preparations chiefly 'Ayurveda/Sidha Bahamas', (herbal-mineral arrangements) and 'Unani' preparations, and even objects similar agates which have coats comprising lead. [50].

Current educations take place forth the estimation that the biochemical arrangement of particulates, particularly the occurrence of small quantities of poisonous chemicals, is a more suitable limit for the valuation of particulate vigor effect slightly than their bulk concentrations [51]. Persons might be wide-open to possibly injurious chemicals, bodily and biotic means in air, food, water, or soil. However, acquaintance does not merely affect the occurrence of a dangerous cause in the surroundings. The important term in the description of the disclosure is interaction [52]. Their necessity is an interaction among the means and the outside periphery of the human body, like the air, the skin, or the mouth. Contact us frequently distinct, for instance, a purpose of attentiveness and period: "a circumstance that occurs just the once there is communication at a boundary in the mid of a human and the heaven through an organic of a precise concentration for an interval of the era" [53]. 


\subsection{Cadmium.}

Cadmium is taken out in the air by usual and anthropogenic means. Volcanoes, windborne elements, and biogenetic releases are reflected as the usual chief causes of cadmium in the air [54]. Tobacco smoke is a vital cause of cadmium acquaintance. Cigarette smoking one packet a day can gulp 5-10 times the cadmium quantity available over consistent food. Nutrition is a bad cause of cadmium. It is conveyed in blood, certain to metallothionein. Urinary secretion is gentle. The natural half-life can be up to 30 years. Maximum attentiveness is established in the kidney and liver. The problem of cadmium toxicity is not recognized in India [50].

\subsection{Lead.}

Airborne lead is a slight acquaintance path. Though, in zones wherever the airborne levels of lead are great, they signify an important, or even controlling, cause of lead acquaintance $[55,56]$. Up to $50 \%$ of breath in the inorganic lead might be engrossed in the lungs. The grown person proceeds up $10-15 \%$ of lead in food, while kids might engross up to $50 \%$ via the gastrointestinal tract. Lead in the blood is certain to erythrocytes, and removal is slowly and primarily via urine. Lead is deposited in the skeleton and is only gently emitted from this body section. The half-life of lead in blood is approximately 1 month and in the skeleton 20-30 years. Headache, irritability, abdominal pain, and several signs connected to the nervous system are acute lead poisoning signs. Lead encephalopathy is considered by vigilance and impatience. Kids might be pretentious by behavior disorders, knowledge, and attentiveness problems [57].

\subsection{Arsenic.}

The concentration of arsenic in gulped air- polluted elements is extremely reliant on the solubility and elements' size. Soluble arsenic compounds are easily absorbed from the gastrointestinal tract. However, inorganic arsenic is widely methylated in humans, and the metabolites are expelled in the urine [58]. In harming the nervous system, liver damage, and peripheral vascular disease, gangrene of the lower limbs can affect the chronic acquaintance. This disorder is generally recognized as 'black foot disease'. Long-lasting acquaintance with arsenic is also connected with leukemia, kidney and bladder cancers, dermatitis, hyperpigmentation, and arsenical keratosis. Non-genotoxic carcinogen turns by the arsenic. Though, it disturbs DNA methylation and repair [59].

\subsection{Zinc.}

Zinc has been described to source the similar marks of sickness as ensures lead, and can merely be incorrectly identified as lead harming [60]. Zinc is measured to be comparatively non-hazardous, particularly if occupied orally. However, excess quantity can cause classification dysfunctions that result in damage to development and reproduction $[61,62,63]$. Vomiting, diarrhea, bloody urine, icterus (yellow mucus membrane), liver failure, kidney failure, and anemia have been described as medical signs of zinc toxicities [64]. The concentration of Zine in lichen thalli and their particular bedrocks reached from 55.772.6 to 118.171.7, then 2.170 .4 to $13.671 .2 \mathrm{mg}$ g1 dry weight, individually, viewing important alteration among locations. The samples composed from locations taking advanced vehicular action presented advanced $\mathrm{Zn}$ gathering tracked by the testers collected from nearby 
agricultural lands. The complex attentiveness of $\mathrm{Pb}$ and $\mathrm{Zn}$ in roadside lichen examples (sites 2 and 3) may be owing to heavy vehicular activity elaborate in this zone. Separately from vehicle release, the abrasion of metallic vehicle parts also emits $\mathrm{Pb}$ and $\mathrm{Cr}$ (vehicle exhaust) and $\mathrm{Zn}$ from the scrape of exhausts and brake pads [65].

\subsection{Mercury.}

Mercury is poisonous and consumes no recognized purpose in human biochemistry and physiology. Inorganic methods of mercury source impulsive abortion inherited deformity and GI disorders (like corrosive esophagitis and hematochezia). It is harmful by its biological procedures, which contain monomethyl and diethyl mercury offerings with erethism (an anomalous annoyance or sensitivity of an organ or body part to stimulation), acrodynia (Pink disease, which is considered by hasty and desquamation of the pointers and feet), gingivitis, stomatitis, neurological disorders, entire injury to the brain and CNS and are likewise related with an inherited malformation [66, 67].

\subsection{Fluoride.}

Toxic kinetic studies demonstrate that engrossed fluoride is dispersed into double partitions. Fluoride in blood and lenient matters has a small half-life of a few hours, then that in solid soft tissue like bone and teeth has an extended half-life of eight years. , The addition in these two muscles is dose and time reliant. In the disease skeletal fluorosis, the limitless gathering of fluoride in bones is the chief source. Fluoride injurious can be severe due to contact to an only huge dose, as it occurs with developed labors (industrialized fluorosis) or enduring (prevalent fluorosis) due to incessant digestion of water and food enclosing great quantities of fluoride. Teeth and bone are the main objectives of both types. Though fluoride ensures not new, soft tissues and sources non-skeletal fluorosis, prevalent fluorosis is a thoughtful problem in numerous portions of India. Dental mottling is the main characteristic feature of dental fluorosis. The medical structures of skeletal fluorosis are; muscular-skeletal dysfunction, arthralgia, arthritis, fixed flexion deformities, restricted movement of joints, stiffness of the spine, and sometimes paraplegia. The development is slow15. In further current ages, an irregular of skeletal fluorosis - genu valgum or knock nee has been described from some portions of the biosphere containing India, in earlier persons. Its etiology is not entirely unspoken. Though consumption of high quantities of fluoride concluded air, water and food is the chief influence in widespread fluorosis, other issues- may be nutritional, also create a role. Thus, In the US, ingestion of even 8 ppm fluoride comprising water over 15 years looks not main to fluorosis. On the further hand, in India, levels above $1 \mathrm{ppm}$ are measured as dangerous. The part of nourishment eminence is ostensible from the detail that even in the fluorotic regions, the poor and undernourished remain the most horrible pretentious [68].

\subsection{Chromium.}

Burning oil and coal, petroleum from Ferro-chromate refractory material, pigment oxidants, catalyst, chromium steel, fertilizers, oil well drilling, and metal plating tanneries occurs the chromium. Anthropogenically, chromium is released into the surroundings, concluded manure and composts. The occurrence of extra chromium outside the permitted range is critical to the vegetation; meanwhile, it strictly disturbs the vegetable's organic tissues and comes in the food chain on the ingesting of these plant constituents. Mutual structures 
owing to $\mathrm{Cr}$ phytotoxicity are the decline in root development, leaf chlorosis, the reticence of seed germination, and miserable biomass. Numerous plants such as maize, wheat, barley, cauliflower, Citrullus, and vegetables are the biological methods affected essentially by the poisonous chromium. Chromium harmful sources chlorosis and necrosis in plants [67]. Enzymes like catalase, peroxidase, and cytochrome oxidase with iron as their component are expensive by chromium poisonous. The catalase action inspired by an extra chromium source persuading poisonous has been deliberate with admiration for photosynthesis, nitrate reductase action, protein content in algae, and photosynthetic colors [69].

\subsection{Nickel.}

Nickel is mostly obtainable in the coalmine surroundings owed to burnt coal production of nickel from fossil fuel quantities to around 70,000 tons per year [70,71]. Nickel is a crucial micronutrient for microorganisms besides animals, however not to plants. It is connected with the fusion of vitamin B. It is poisonous at 12 advanced deliberations. A suggested everyday nutritional consumption of nickel is approximately 300-600 mg per day. Only $1-10 \%$ of the nutritional swallowed nickel is engrossed [69]. Asthma, CNS effects, gastrointestinal effects, headache, neoplasia of lung, and respiratory tract are approximately mutual health effects credited to nickel acquaintance [72]. Some of the supreme hazardous causes of nickel contamination are nickel carbonyl, which is the airborne waste from industrialized components. Early signs of poisonous owing to nickel carbonyl are nausea, dizziness, headache, and chest pain. Severe pulmonary symptoms, tachycardia, and extreme weakness develop after 1 to 5 days, and within 4 to 13 days, even death may occur. Nickel dust is stated to be carcinogenic.

\subsection{Copper.}

Copper is too an important component of usual organic actions in humans. Burning of coal, fertilizer, and iron steel production contains the Cause of atmospheric copper airborne contamination by copper consequences from the release of excavation followings and flies ash [70]. Copper is mostly engrossed from the duodenum in males. Besides its retaining, it is influenced by the biochemical procedure in which the metal is swallowed. Ingestion of 15-75 $\mathrm{mg}$ of copper a day affects gastrointestinal syndromes. Incessant ingestion of copper from nutrition, air, and water might give rise to long-lasting copper harming, and a syndrome named hepatolenticular deterioration or 'Wilson's disease' might grow. In addition, extreme consumption of copper might give rise to hemolysis, hepatotoxic and nephrotoxic effects. Additional circumstances that enlarged copper filings in the liver contain thalassemia Mediterranean Anaemia. Hemochromatosis, cirrhosis, atrophy of the liver, tuberculosis, and carcinoma [69]. Though, injury of the capability to engross copper resultant in its lack is known as Manke's illness [70]. The breathing of air copper gives rise to the annoyance of the respirational area and metallic emission illness.

\subsection{Manganese.}

Manganese is a vital trace component by little meditations then poisonous at advanced absorptions. The burning of coal in the surroundings is prevented by the manganese [70]. The usage of manganese in approximate fertilizers too adds to liquid and airborne pollution [69], in $31 \%$ of usual water testers, the manganese meditation. Regular payment of $2.5-5 \mathrm{mg}$ of manganese is suggested for humans, which turns as a cofactor in enzymatic reactions such as 
phosphorylation, a mixture of fatty acids, and cholesterol. Though exposed to developed stages of manganese, it accrues in the kidney, liver, and bones. The usual health special effect that might grow in humans contains cirrhosis, influenza, metal-fume fever, and bronchitis [71]. Enduring disclosure to manganese gives rise to 'Manganese Psychosis', an irreparable brain illness categorized by irrepressible happiness, elation, thoughtlessness, sexual enjoyment shadowed by impotency speech incapacity [69]. The breath revelation to manganese causes added lethal illness named as 'Manganese Pneumonia' [70]. Though, there is no certain proof on the fundamental association between manganese contamination and prostate cancer, teratogenic and mutagenic effect of these constituents.

\section{Hazardous gases found in airborne chemicals}

Environmentally injurious gases comprise poisonous gases like $\mathrm{H}_{2} \mathrm{~S}, \mathrm{CO}$, and $\mathrm{NH}_{3}$, greenhouse gases are like $\mathrm{N}_{2} \mathrm{O}, \mathrm{CH}_{4}$, and $\mathrm{CO}_{2}$, and superior gases such as $\mathrm{NO}_{2}, \mathrm{NO}$, and $\mathrm{SO}_{2}$, which are together poisonous and greenhouse gases. A rapid for the bodily goods, cause of production, poisonousness, and American Conference of Government Industrial Hygienists stated the harmful gases ecologically by the threshold limit value (TLV). TLV is distinct as the supreme attentiveness of a biochemical permissible for frequent contact deprived of creating opposing health special effects [73].

\subsection{Nitrogen oxides $\left(\mathrm{NO}_{2}\right.$ and $\left.\mathrm{NO}\right)$.}

Nitrogen oxides $\left(\mathrm{NO}_{2}\right.$ and $\left.\mathrm{NO}\right)$ are poisonous gases that ignition biochemical plant life and vehicles. Amongst the nitrogen dioxide $\left(\mathrm{NO}_{2}\right)$ is the supreme harmful gas with TLV of 3 ppm. $\mathrm{NO}_{2}$ also shows the main part in full of atmosphere responses that goods ground-level ozone, the foremost essential of the smoke. In the circumstance of consuming gases from influence stations, the chief constituent of air produced. NOx combination is nitric oxide (NO, 90-95\% overall), reaching from 0 to $4000 \mathrm{ppm}$. NO is comparatively fewer poisonous associated with $\mathrm{NO}_{2}$. However, $\mathrm{NO}$ causes acid rains, photochemical pollution, and the manufacture of ozone. The exposure and the release control of nitrogen oxides are vital to decreasing their harmful special effects on ecological and human beings [74]. The $\mathrm{N}_{2} \mathrm{O}$ reaction of $\mathrm{SnO}_{2}$ loaded with $0.5 \mathrm{wt} \% \mathrm{SrO}$ presented $\mathrm{N}_{2} \mathrm{O}$ reaction 3 times as great as that of unburdened $\mathrm{SnO}_{2}$. It could identify $\mathrm{N}_{2} \mathrm{O}$ in the air in the attentiveness variety of $10-300 \mathrm{ppm}$ at $500{ }^{\circ} \mathrm{C}$. Also, gold burdened polycrystalline tin oxide ( $\mathrm{SnOx}$ ) grownup by $\mathrm{ArF}$ excimer laser-induced metallic organic biochemical vapor statement displayed a reaction of 11.5 to $\sim 100 \mathrm{ppm} \mathrm{N}_{2} \mathrm{O}$ at $210 \circ \mathrm{C}[75]$.

\subsection{Hydrogen sulfide $\left(\mathrm{H}_{2} \mathrm{~S}\right)$.}

Hydrogen sulfide $\left(\mathrm{H}_{2} \mathrm{~S}\right)$, the supreme hazardous compost gas, is categorized by way of a biochemical asphyxiate. It relates chemically directly by blood's hemoglobin and lumps oxygen after existence is accepted to physique's vigorous structures and soft tissue. It remains shaped after the anaerobic decay of biological constituents such as fertilizer. Its typical rottenegg odor is informal to be noticed at little attention. H2S will paralyze the common sense of odor by advanced absorptions, giving somebody a false logic of safety. It will source immediate paralysis and demise when the attentiveness surpasses TLV worth. After the security idea of vision, now situ recognition, then observing of $\mathrm{H} 2 \mathrm{~S}$ is] significant in petrochemical and coal developed activities [76]. 


\subsection{Carbon monoxide (CO).}

Carbon monoxide (CO) exists as a colorless poisonous gas, using no odor, producing one untraceable to individuals. It is formed owed to the partial incineration of gases. It usually originates now the release of vehicle consumes. The gas devices are there exposed to fix irrevocably to the iron center of hemoglobin, the oxygen-carrying particle in blood. The irreparable obligatory resources that oxygen can no longer be engrossed cause harm to the human body through a decrease in cellular breathing and great stages of CO contact consequences in demise. TLV is occasionally stated away as IDLH (instantaneously hazardous to lifespan and health). The significance for CO assumed by the National Air Quality Standards by the UK administration in January 2000 is presently by an attentiveness of $10 \mathrm{ppm}$ for $8 \mathrm{~h}$ of contact. Even at absorptions well under the IDLH level, $\mathrm{CO}$ can have an undesirable special effect on human fitness [72].

\subsection{Ammonia $\left(\mathrm{NH}_{3}\right)$.}

Ammonia (NH3) exists as a colorless gas through a usual pungent smell. Ammonia underwrites considerably for global organisms' nutritious desires by portion as an originator to nutrition and manures. Ammonia, also straight or circuitously, is also a structured mass for the mixture of numerous medicines. It is moreover recycled in washing goods. In spite of its practicality, ammonia is together corrosive and risky to humans, particularly once its concentration surpasses TLV value of $25 \mathrm{ppm}$.

\subsection{Sulfur dioxide $\left(\mathrm{SO}_{2}\right)$.}

Sulfur dioxide $\left(\mathrm{SO}_{2}\right)$ is colorless smoke. These odors are similar to burnt matches. It can be reacted to sulfur trioxide, which is willingly distorted to sulfuric acid haze in the occurrence of water vapor. $\mathrm{SO}_{2}$ can be reacted to form acid aerosols. $\mathrm{SO}_{2}$ is an originator to sulfates, of the main constituents of the air's respirable atoms, which are unique. Health special effects produced through contact to great heights of $\mathrm{SO}_{2}$ contain living difficulties, respirational infection, altering the lung's fortifications, deteriorating respirational and circulatory illness. Persons with asthma or long-lasting lung or heart illness are the supreme delicate to $\mathrm{SO}_{2}$. It also harms plants and yields. $\mathrm{SO}_{2}$ laterally with nitrogen oxides are the chief originators of acid rain. These funds to the acidification of ponds and rivers enhanced erosion of constructions and compact perceptibility. $\mathrm{SO}_{2}$, moreover, sources increase of microscopic acid sprays, which have thoughtful healthiness inferences as well as causal towards weather alteration.

\subsection{Carbon dioxide $\left(\mathrm{CO}_{2}\right)$.}

Carbon dioxide (CO2) is a colorless, odorless noncombustible gas. It is the supreme protuberant greenhouse gas in World's air with the influence of $76 \%$ in the Earth's atmosphere, further methane (13\%), nitrous oxide (6\%), and fluorocarbon $(5 \%)$. It is used to conclude the atmosphere by the procedure photosynthesis, which makes human life probable. Photosynthesis is the method of green plants and other creatures altering light energy into biochemical vigor. Light energy is stuck and recycled to change carbon dioxide, water, and added raw materials into oxygen and energy ironic organic compounds. Carbon dioxide is produced into the airborne as a human breathes out, injuries fossil fuels for vigor, and deforests the Earth. Each year humans add over 30 billion tons of carbon dioxide to these courses' atmosphere, and it is high $30 \%$ as 1750 [72]. 


\subsection{Methane $\left(\mathrm{CH}_{4}\right)$.}

Methane $\left(\mathrm{CH}_{4}\right)$ is an odorless, colorless combustible fume. It is used mainly as fuel to produce warmth and brightness. It is similarly used for the production of biological chemicals. Methane could be designed through the deterioration of usual constituents besides is shared in landfills, marshes, septic systems, and drains. Methane can procedure a volatile combination in the air at phases as little as $5 \%$. Methane could similarly remain to originate in petroleum gas. Methane was an influential greenhouse gas formed together certainly and concluded human actions.

\subsection{Nitrous dioxide $\left(\mathrm{N}_{2} \mathrm{O}\right)$.}

Nitrous dioxide $\left(\mathrm{N}_{2} \mathrm{O}\right)$, too named laughing gas, is comprehensively used for medical processes such as an anesthetic trip. It is not similar to poisonous $\mathrm{NO}_{2}$ and $\mathrm{NO}$, but $\mathrm{N}_{2} \mathrm{O}$ is a greenhouse gas with actual in height worldwide heating constant, which is around 300 times as great as that of $\mathrm{CO}_{2}$, producing thoughtful ozone layer disturbance. The ecological monitoring of greenhouse gases is vital to aid go-slow worldwide heating [77]. Oxides of nitrogen releases have also compact but distant less than those of sulfur dioxide mainly since low panels practical to the street automobile fleet, which have only lately ongoing to influence NOx emissions. Nitrate has not shown a proportionate reduction [78].

\section{Environmental effects of toxic airborne chemicals}

\subsection{Environmental effects on nature.}

Environmental economics emphasizes all the different scraps of proofs relating to the ecological value, and the commercial routine of persons, collections, and administrations and consuming attained a great level of economic growth and physical affluence. The query is: What decent is substantial wealth if it originates at the rate of enormous disturbances of the environment by which we are sustained? [79-83]. The third group of studies has absorbed measuring the ecological influences of nutritional alterations, such as falling meat ingesting and growing plant and fruit intake [81]. Additional important is the detail that with current economic, demographic, and technical enlargements around the biosphere, the related ecological consequences are flattering abundant, more widespread, and lethal. What once were local ecological influences, effortlessly corrected, have now developed extensive special effects that might well turn out to be irreversible. Certainly, approximately of our supreme troublesome worries nowadays are around global ecological influences like ozone layer depletion, global warming, and climate alteration. It is no curiosity then that the eminence of the normal surroundings has developed the main emphasis on public and worldwide anxiety. Ecological economics's asset lies in the detail that it is logical and contracts with thoughts such as competence, trade-offs, costs, and welfares [84].

\subsection{Environmental effects on human health.}

Environmental chemicals cause a number of chemosensory difficulties. They did not simply make invasive sense of taste and odors in and of themselves, but they can also finish chemosensory tissue. It is not astonishing that the substance sanities are particularly susceptible to environmental contamination since they are exactly intended to interact and observe our outside biochemical environment. Human beings respire completed together by the nose and 
the mouth; thus, airborne chemicals can arise in interaction with chemosensory receptors for odor and sense of taste. Chemicals can also be consumed in liquid and nutrition and spread chemosensory receptors from the body fluid [85]. Natural or else characteristic special effects of the deposited elements stay resolute by the elements' natural biochemical surroundings, the place of deposition inside the lungs, and physiologic reaction to the elements. Approximately 3000 diverse anthropogenic airborne chemicals have been recognized, of which only for around 200 such elements, the influence on location and human beings has been examined to a distinguished amount [86]. Ecological air organizes comprise a composite compound of toxics, containing particulate matter (PM), irritant gases, and benzene. The atoms' biochemical arrangement does differ importantly and is influenced by many physical, meteorological, and source-specific variables. Usually, ecological elements contain inorganic constituents (sulfates, nitrates, ammonium, chloride, and trace metals), essential and organic carbon, biological components (bacteria, spores, and pollens), and adsorbed volatile and semi-volatile organic compounds [87]. Human fitness is the cause of alteration by an organism to its own inner surroundings and to its outside surroundings.

The Connection among the geologic surroundings and regional and local differences in long-lasting illnesses such as cancer and heart disease has remained perceived for numerous ages [88]. Proof signifying a suggestion among the geochemical surroundings and enduring illnesses endures collecting. Human health might be pretentious by the quantity of sure biochemical rudiments obtainable from food, water consumption, and the atmosphere [89, 90]. In industrialized states, the suggestion amid innate geochemistry and human intake of these materials in food and water might be of low order [91]. In emerging states, where local civilizations live earlier to the land, persons are more undefended to their geochemical environments then agonize many health problems [92,93, 94]. PM has been related to cancer, diabetes, cardiovascular diseases, hypertension, respiratory, and neurological diseases [95]. Insufficient studies have inspected dangers related to passive smoking [96]. Likewise, approximately current studies establish a strong association between nonrenewable energy ingesting and ecological deprivations [97,98]. In a cohort of French women from the education system, ever-smokers with passive smoking exposure during childhood had a higher risk of RA than smokers with no passive smoking during childhood [99]. There has been an enormous increase in the production of different chemicals during the last several decades throughout the world. Although these chemicals have proven to be useful for many aspects of modern life, it is increasingly recognized that they may pollute the environment and cause harm to human beings to a varying extent. Of the thousands of manufactured chemicals, it is estimated that about 1000 may have endocrine-acting properties [100]. As a surrogate marker for OSA, selfreported habitual snoring is also related to many adverse health outcomes, such as chronic kidney disease [101]. It has been found that 11 million deaths and 255 million disabilityadjusted life years (DALYs) are attributable to dietary risk factors [102]. For instance, during the research of the global burden of diseases for low- and middle-income countries, [104] mentioned the consequences of diseases and mortality on human capital as well as on gross profit in the form of low productivity. Therefore, several authors have suggested the investigation of PM source contribution to OP [105-107], as a relevant indicator to identify the sources with high potential toxic effects on human health, are an integral part of the leachate [108-119]. 


\section{Discussion}

Hazardous Airborne Chemicals are very harmful to the surroundings and human healthiness also. These harmful airborne chemicals present everywhere. Some of the analytical instruments used to detect the toxic airborne chemicals and gases are flame ionization detector (FID), Photo-ionisation detector (PID), specialized Gas chromatographs (GC), Gas chromatography- Mass Spectrometry, etc. SEM-EDS is also the analytical technique used for the detection of particulate matter (PM10 and PM25). It is very harmful nowadays all over the world. Airborne chemicals were the source of contamination in terrestrial and aquatic ecosystems. Despite such high levels, the lack of studies, especially in the field of environmental epidemiology, is discouraging. Further research is required to solve the problems and their consequences affecting the environment and human health.

\section{Conclusion}

Airborne chemicals are released by various sources such as extreme fires, poisonous industrial gases, biomass burning, railroad cars, trucks emission, etc. The major diseases caused by the toxic airborne chemicals are asthma, bronchitis, emphysema, headache, irritation of eyes, anxiety, fatigue, respiratory diseases, chronic obstructive pulmonary disease (COPD), etc. Monitoring the exposure and probable intervention for reducing additional exposure to heavy metals in the environment and in humans can become a momentous step towards prevention.

\section{Funding}

This research received no external funding.

\section{Acknowledgments}

This research has no acknowledgment.

\section{Conflicts of Interest}

The authors declare no conflict of interest.

\section{References}

1. Raabe O.G. Respiratory exposure to air pollutants. In: Air pollutants and the respiratory tract. eds. Swift, D.L. and W. M. Foster, New York: Marcel Dekker. 1999, pp. 39-73.

2. Callén, M.S.; de la Cruz, M.T.; López, J.M.; Navarro, M.V.; Mastral, A.M. Comparison of receptor models for source apportionment of the PM10 in Zaragoza (Spain). Chemosphere 2009, 76, 1120-1129, https://doi.org/10.1016/j.chemosphere.2009.04.015.

3. Lind, M.-L.; Boman, A.; Sollenberg, J.A.N.; Johnsson, S.; Hagelthorn, G.; Meding, B. Occupational Dermal Exposure to Permanent Hair Dyes Among Hairdressers. The Annals of Occupational Hygiene 2005, 49, 473480, https://doi.org/10.1093/annhyg/mei030.

4. Baeyens, W.; Dehairs, F.; Dedeurwaerder, H. Wet and dry depostion fluxes above the North Sea. Atmospheric Environment. Part A. General Topics 1990, 24, 1693-1703, https://doi.org/10.1016/09601686(90)90503-F.

5. Moore, J.W.; Ramamoorthy, S. Heavy Metals in Natural Waters. Springer Verlag, 1984, New York.

6. Natusch, D.F.; Wallace, J.R. Urban aerosol toxicity: The influences of particle size. Science 1974, 86, 694698, https://doi.org/10.1126/science.186.4165.695.

7. Migon, C.; Journel, B.; Nicolas, E. Measurement of trace metal wet, dry and total atmospheric fluxes over the Ligurian Sea. Atmospheric Environment 1997, 31, 889-896, https://doi.org/10.1016/S13522310(96)00242-7. 
8. Irwin. Down to Earth Leading to pollution. Centre for Science and Environment, New Delhi, 1997.

9. Agarwal, A.; Narain, S. The citizen's fifth report. Part II. Statistical database. Centre for Science and Environment, New Delhi 1999.

10. Bakand, S.; Winder, C.; Khalil, C.; Hayes, A. Toxicity Assessment of Industrial Chemicals and Airborne Contaminants: Transition from In Vivo to In Vitro Test Methods: A Review. Inhalation toxicology 2005, 17, 775-787, http://dx.doi.org/10.1080/08958370500225240.

11. US Office of Technology Assessment. Transportation of Hazardous Materials. 1986, Washington, DC: GPO.

12. Samara, C.; Voutsa, D.; Kouimtzis, T.; Bournis, N.; Tsani, E. Characterization of airborne particulate matter in thessaloniki, Greece. Toxicological \& Environmental Chemistry 1990, 29, 107-119, https://doi.org/10.1080/02772249009357625.

13. Singh, G.; Sharma, P.K. A study of spatial distribution of air pollutants in some coal mining areas of Raniganj coalfield, India. Environment International 1992, 18, 191-200, https://doi.org/10.1016/01604120(92)90006-P.

14. Engling, G.; Gelencser, A. Atmospheric brown clouds: from local air pollution to climate change. Elements 2010, 6, https://doi.org/10.2113/gselements.6.4.223.

15. Gustafsson, Ö.; Kruså, M.; Zencak, Z.; Sheesley, R.J.; Granat, L.; Engström, E.; Praveen, P.S.; Rao, P.S.P.; Leck, C.; Rodhe, H. Brown Clouds over South Asia: Biomass or Fossil Fuel Combustion? J Science 2009, 323, 495-498, https://doi.org/10.1126/science.1164857.

16. Van Duijvenbooden, W. December. Monitoring. In: Symposium Atmospheric Deposition and Soil Quality. Ede, N.L. 1992.

17. Ham, J. Discussion about the national model for dispersion of air pollution. Lucht 1992, 9, 84-85.

18. Kelly, F.J.; Fussell, J.C. Toxicity of airborne particles — established evidence, knowledge gaps and emerging areas of importance. Philosophical Transactions of the Royal Society A 2020, 378, https://doi.org/10.1098/rsta.2019.0322.

19. Dong, C.-D.; Chen, C.-W.; Chen, Y.-C.; Chen, H.-H.; Lee, J.-S.; Lin, C.-H. Polystyrene microplastic particles: In vitro pulmonary toxicity assessment. Journal of Hazardous Materials 2020, 385 , https://doi.org/10.1016/j.jhazmat.2019.121575.

20. Poma, A.; Vecchiotti, G.; Colafarina, S.; Zarivi, O.; Aloisi, M.; Arrizza, L.; Chichiriccò, G.; Di Carlo, P. In Vitro Genotoxicity of Polystyrene Nanoparticles on the Human Fibroblast Hs27 Cell Line. Nanomaterials 2019, 9, https://doi.org/10.3390/nano9091299.

21. Jeong, J.; Garcia-Reyero, N.; Burgoon, L.; Perkins, E.; Park, T.; Kim, C.; Roh, J.-Y.; Choi, J. Development of Adverse Outcome Pathway for PPAR $\gamma$ Antagonism Leading to Pulmonary Fibrosis and Chemical Selection for Its Validation: ToxCast Database and a Deep Learning Artificial Neural Network Model-Based Approach. Chemical Research in Toxicology 2019, 32, 1212-1222, https://doi.org/10.1021/acs.chemrestox.9b00040.

22. Harrison, R.M. Airborne particulate matter. Philosophical Transactions of the Royal Society A: Mathematical, Physical and Engineering Sciences 2020, 378, https://doi.org/10.1098/rsta.2019.0319.

23. Brean, J.; Harrison, R.M.; Shi, Z.; Beddows, D.C.S.; Acton, W.J.F.; Hewitt, C.N.; Squires, F.A.; Lee, J. Observations of highly oxidized molecules and particle nucleation in the atmosphere of Beijing. Atmos. Chem. Phys. 2019, 19, 14933-14947, https://doi.org/10.5194/acp-19-14933-2019.

24. Mortamais, M.; Pujol, J.; Martínez-Vilavella, G.; Fenoll, R.; Reynes, C.; Sabatier, R.; Rivas, I.; Forns, J.; Vilor-Tejedor, N.; Alemany, S.; Cirach, M.; Alvarez-Pedrerol, M.; Nieuwenhuijsen, M.; Sunyer, J. Effects of prenatal exposure to particulate matter air pollution on corpus callosum and behavioral problems in children. Environmental Research 2019, 178, https://doi.org/10.1016/j.envres.2019.108734.

25. Shah, R.U.; Coggon, M.M.; Gkatzelis, G.I.; McDonald, B.C.; Tasoglou, A.; Huber, H.; Gilman, J.; Warneke, C.; Robinson, A.L.; Presto, A.A. Urban Oxidation Flow Reactor Measurements Reveal Significant Secondary Organic Aerosol Contributions from Volatile Emissions of Emerging Importance. Environmental Science \& Technology 2020, 54, 714-725, https://doi.org/10.1021/acs.est.9b06531.

26. Alloway, B.J.; Ayres, D.C. Chemical Principles of Environmental Pollution, B.J. Alloway and D.C. Ayres. Water, Air, and Soil Pollution 1998, 102, 216-218, https://doi.org/10.1023/A:1004986209096.

27. Brunekreef, B.; Maynard, R.L. A note on the 2008 EU standards for particulate matter. Atmospheric Environment 2008, 42, 6425-6430, https://doi.org/10.1016/j.atmosenv.2008.04.036.

28. Schroeder, W.H.; Dobson, M.; Kane, D.M.; Johnson, N.D. Toxic Trace Elements Associated with Airborne $\begin{array}{llllll}\text { Particulate } & \text { Matter: A } & \text { 1267-1285, }\end{array}$ https://doi.org/10.1080/08940630.1987.10466321.

29. Rai, P.K. Environmental magnetic studies of particulates with special reference to biomagnetic monitoring using roadside plant leaves. Atmospheric Environment 2013, 72, 113-129, https://doi.org/10.1016/j.atmosenv.2013.02.041.

30. CPCB, Air Quality Monitoring, Emission Inventory and Source Apportionment Study for Indian cities. Central Pollution Control Board, the Government of India. New Delhi, India. 2010. 
31. Kumar, A.V.; Patil, R.S.; Nambi, K.S.V. Source apportionment of suspended particulate matter at two traffic junctions in Mumbai, India. Atmospheric Environment 2001, 35, 4245-4251, https://doi.org/10.1016/S13522310(01)00258-8.

32. Parveen, R.; Saini, R.; Taneja, A. Chemical characterization and health risk assessment of soil and airborne particulates metals and metalloids in populated semiarid region, Agra, India. Environmental Geochemistry and Health 2018, 40, 2021-2035, https://doi.org/10.1007/s10653-016-9822-4.

33. World Health Report, Reducing risks, promoting health life. World Health Organization,Geneva. 2002, https://books.google.co.in/books?hl=en\&lr=\&id=epuQi1PtY_cC\&oi=fnd\&pg=PA9\&dq=33.\%09.

34. Saunders, P.J.W/; Godzik, S. Terrestrial vegetation-air pollutant interactions: non-gaseous air pollutants. In: Air Pollutants and Their Effects on the Terrestrial Ecosystem. In: Advances in Environmental Science and Technology. Legge, A.H.; Krupa, S.V. eds. Wiley, New York, USA.Volume 18, 1986, pp. 389-394.

35. Garner, J.H.B. Nitrogen oxides, plant metabolism, and forest ecosystem response. In: Plant Responses to the Gaseous Environment: Molecular, Metabolic and Physiological Aspects. Alscher, R.G.; Wellburn, A.R. eds. Chapman and Hall, London, UK; 1994; pp. 301-314, https://doi.org/10.1007/978-94-011-1294-9_16.

36. Mohanraj, R.; Azeez, P.A. Health effects of airborne particulate matter and the Indian scenario. Current Science 2004, 87, 741-748.

37. Santosh, K.P.; Tripathi, B.D. Biomonitoring trace-element levels in PM10 released from vehicles using leaves of Saraca indica and Lantana camara. AMBIO 2007, 36, 704-705, https://doi.org/10.1579/00447447(2007)36[704:BTLIPR]2.0.CO;2.

38. Park, S.S.; Kim, Y.J. Source contributions to fine particulate matter in an urban atmosphere. Chemosphere 2005, 59, 217-226, https://doi.org/10.1016/j.chemosphere.2004.11.001.

39. Vallius, M.; Janssen, N.A.H.; Heinrich, J.; Hoek, G.; Ruuskanen, J.; Cyrys, J.; Van Grieken, R.; de Hartog, J.J.; Kreyling, W.G.; Pekkanen, J. Sources and elemental composition of ambient PM2.5 in three European cities. Science of The Total Environment 2005, 337, 147-162, https://doi.org/10.1016/j.scitotenv.2004.06.018.

40. Leys, J.F.; Larney, F.J.; Müller, J.F.; Raupach, M.R.; McTainsh, G.H.; Lynch, A.W. Anthropogenic dust and endosulfan emissions on a cotton farm in northern New South Wales, Australia. Science of The Total Environment 1998, 220, 55-70, https://doi.org/10.1016/S0048-9697(98)00242-3.

41. Manins, P.; Allan, R.; Beer, T. Atmosphere. Australia State of the Environment Report 2001 (Theme Report). CSIRO Publishing, Melbourne, Australia 2001.

42. Guerreiro C; Larssen S; de Leeuw F; Air Quality in Europe. Copenhagen, European Environment Agency, 2011, Available from www.eea.europa.eu/publications/air-quality-in-europe-2011.

43. Mohanraj, R.; Azeez, P.A. Urban development and particulate air pollution in Coimbatore city, India. International Journal of Environmental Studies 2005, 62, 69-78, https://doi.org/10.1080/0020723042000261713.

44. Gupta, A.K.; Karar, K.; Srivastava, A. Chemical mass balance source apportionment of PM10 and TSP in residential and industrial sites of an urban region of Kolkata, India. Journal of Hazardous Materials 2007, 142, 279-287, https://doi.org/10.1016/j.jhazmat.2006.08.013.

45. Prata, J.C. Airborne microplastics: Consequences to human health? Environmental Pollution 2018, 234, 115 126, https://doi.org/10.1016/j.envpol.2017.11.043.

46. Migon, C.; Journel, B.; Nicolas, E. Measurement of trace metal wet, dry and total atmospheric fluxes over the Ligurian Sea. Atmospheric Environment 1997, 31, 889-896, https://doi.org/10.1016/S13522310(96)00242-7.

47. Pacyna, J.M.; Nriagu, J.O. Atmospheric Emissions of Chromium from Natural and Anthropogenic Source', in Chromium in the Natural and Human Environments. Advances in Environmental Science and Technology Wiley, New York, 1988, 105.

48. Pacyna, J.M.; Hutchinson, T.C.; Meeme, K.M. Lead, Mercury, Cadmium and Arsenic in the Environment. Wiley, Chichester 1987.

49. Verma, P.C. Studies on suspended particulate matter in the general atmosphere of an industrial area. Indian J. Environ. Prot. 1989, 9, 781-785.

50. Marg, B.Z. Hazardous metals and minerals pollution in India: Sources, toxicity and management. A Position Paper, Indian National Science Academy, New Delhi 2011.

51. Forsberg, B.; Hansson, H.C.; Johansson, C.; Areskoug, H.; Persson, K.; Järvholm, B. Comparative health impact assessment of local and regional particulate air pollutants in Scandinavia. Ambio 2005, 34, 11-19.

52. Berglund, M.; Elinder, C.G.; Järup, L. Humans Exposure Assessment. An Introduction. WHO/SDE/ $\mathrm{OEH} / 01.32001$.

53. NRC; Human Exposure Assessment for Airborne Pollutants. Advances and Opportunities. Washington, DC: National Research Council, National Academy Press, 1991.

54. Nriagu, J.O. A global assessment of natural sources of atmospheric trace metals. Nature 1989, 338, 47-49, https://doi.org/10.1038/338047a0.

55. Ikeda, M.; Zhang, Z.-W.; Shimbo, S.; Watanabe, T.; Nakatsuka, H.; Moon, C.-S.; Matsuda-Inoguchi, N.; Higashikawa, K. Exposure of women in general populations to lead via food and air in East and Southeast 
Asia. American Journal of Industrial Medicine 2000, 38, 271-280, https://doi.org/10.1002/10970274(200009)38:3<271::AID-AJIM5>3.0.CO;2-3.

56. Ikeda, M.; Zhang, Z.-W.; Shimbo, S.; Watanabe, T.; Nakatsuka, H.; Moon, C.-S.; Matsuda-Inoguchi, N.; Higashikawa, K. Urban population exposure to lead and cadmium in east and south-east Asia. Science of The Total Environment 2000, 249, 373-384, https://doi.org/10.1016/S0048-9697(99)00527-6.

57. WHO. Arsenic and Arsenic Compounds. Environmental Health Criteria, Geneva: World Health Organization 2001, 224.

58. WHO. Lead. Environmental Health Criteria. Geneva: World Health Organization 1995, 165.

59. De Chaudhuri, S.; Ghosh, P.; Sarma, N.; Majumdar, P.; Sau Tanmoy, J.; Basu, S.; Roychoudhury, S.; Ray, K.; Giri Ashok, K. Genetic Variants Associated with Arsenic Susceptibility: Study of Purine Nucleoside Phosphorylase, Arsenic (+3) Methyltransferase, and Glutathione S-Transferase Omega Genes. Environmental Health Perspectives 2008, 116, 501-505, https://doi.org/10.1289/ehp.10581.

60. McCluggage, D; Heavy Metal Poisoning, NCS Magazine. Published by The Bird Hospital, CO, U.S.A. 1991,

61. Institute of Environmental Conservation and Research INECAR Position Paper Against Mining in RapuRapu, Published by INECAR, Ateneo de Naga University, Philippines 2000.

62. Nolan, K. Copper Toxicity Syndrome. J. Orthomol. Psychiatry 2003, 12, 270-282.

63. Sankhla, M.S.; Kumar, R.; Shefali. New and Advanced Technologies in Aquaculture to Support Environmentally Sustainable Development. Microbial Biotechnology: Basic Research and Applications, Springer 2020, 1, 249-263, https://doi.org/10.1007/978-981-15-2817-0_11.

64. Fosmire, G.J. Zinc toxicity. The American Journal of Clinical Nutrition 1990, 51, 225-227, https://doi.org/10.1093/ajcn/51.2.225.

65. Ward, N.I.; Sampson, K.E. The use of bryophytes and lichens to monitor the rate of metal deposition along the London orbital (M25) motorway. Heavy metals in the environment. PProc. Of the Int. conference, Geneve 1989, 2, 444-7.

66. Ferner, D.J. Toxicity, heavy metals. eMedicine Journal 2001, 2.

67. Verma, R.; Singh Sankhla, M.; Kumar, R. Mercury Contamination in Water \& Its Impact on Public Health. International Journal of Forensic Science 2018, 1, 73-78.

68. Das, A.A. Text book of Human Nutrition. 3rd edition, Bamji, M.S.; Krishnaswamy, K.; Brahmam, G.N.V. editors, Oxford IBH, New Delhi. 2010.

69. Ghani, A. Effect of chromium toxicity on growth, chlorophyll and some mineral nutrients of brassica juncea L. Egyptian Academic Journal of Biological Sciences, H. Botany 2011, 2, 9-15, https://doi.org/10.21608/eajbsh.2011.17007.

70. Nath, K.; Shyam, S.; Singh, D.; Sharma, Y. Effect of chromium and tannery effluent toxicity on metabolism and growth in cowpea (Vigna sinensis L. Saviex Hassk) seedling. Res. Environ. Life. Sci. 2008, 1, 91-94.

71. Dara, S.S. A Textbook of Environmental Chemistry and Pollution Control. S. Chand, New Delhi 1993, 214.

72. Krishnan, K. Fundamentals of Environmental Pollution. S. Chand, New Delhi 1995, 366.

73. Asante-Duah, D.K. Hazardous Waste Risk Assessment. Lewis Publisher 1993, 384.

74. Wetchakun, K.; Samerjai, T.; Tamaekong, N.; Liewhiran, C.; Siriwong, C.; Kruefu, V.; Wisitsoraat, A.; Tuantranont, A.; Phanichphant, S. Semiconducting metal oxides as sensors for environmentally hazardous gases. Sensors and Actuators B: Chemical 2011, 160, 580-591, https://doi.org/10.1016/j.snb.2011.08.032.

75. Brunet, J.; Spinelle, L.; Pauly, A.; Dubois, M.; Guerin, K.; Bouvet, M.; Varenne, C.; Lauron, B.; Hamwi, A. All-organic device with integrated chemical filter dedicated to the selective measurement of NO2 in air. Organic Electronics 2010, 11, 1223-1229, https://doi.org/10.1016/j.orgel.2010.04.021.

76. Chaturvedi, A.; Mishra, V.N.; Dwivedi, R.; Srivastava, S.K. Selectivity and sensitivity studies on plasma treated thick film tin oxide gas sensors. Microelectronics Journal 2000, 31, 283-290, https://doi.org/10.1016/S0026-2692(99)00147-0.

77. Gong, J.; Chen, Q.; Lian, M.-R.; Liu, N.-C.; Stevenson, R.G.; Adami, F. Micromachined nanocrystalline silver doped SnO2 H2S sensor. Sensors and Actuators B: Chemical 2006, 114, 32-39, https://doi.org/10.1016/j.snb.2005.04.035.

78. Feng, J.; Chan, E.; Vet, R. Air quality in the eastern United States and Eastern Canada for 1990-2015: 25 years of change in response to emission reductions of SO2 and NOx in the region. Atmos. Chem. Phys. 2020, 20, 3107-3134, https://doi.org/10.5194/acp-20-3107-2020.

79. Min, Y.; Tuller, H.L.; Palzer, S.; Wöllenstein, J.; Böttner, H. Gas response of reactively sputtered ZnO films on Si-based micro-array. Sensors and Actuators B: Chemical 2003, 93, 435-441, https://doi.org/10.1016/S0925-4005(03)00170-9.

80. Yadav, H.; Kumar, R.; Sankhla, M.S. Residues of Pesticides and Heavy Metals in Crops Resulting in Toxic Effects on Living Organism. Journal of Seybold Report 2020, 15, 1527-1541.

81. Aleksandrowicz, L.; Green, R.; Joy, E.J.M.; Harris, F.; Hillier, J.; Vetter, S.H.; Smith, P.; Kulkarni, B.; Dangour, A.D.; Haines, A. Environmental impacts of dietary shifts in India: A modelling study using nationally-representative data. Environment International 2019, 126, 207-215, https://doi.org/10.1016/j.envint.2019.02.004. 
82. Arora, N.; Jaiswal, K.K.; Kumar, V.; Vlaskin, M.S.; Nanda, M.; Pruthi, V.; Chauhan, P.K. Small-scale phyco-mitigation of raw urban wastewater integrated with biodiesel production and its utilization for aquaculture. Bioresource Technology 2020, 297, https://doi.org/10.1016/j.biortech.2019.122489.

83. Chen, Y.; Yu, W.; Zheng, R.; Li, J.-Y.; Zhang, L.; Wang, Q.; Yin, J.; Jin, L. Magnetic activated carbon (MAC) mitigates contaminant bioavailability in farm pond sediment and dietary risks in aquaculture products. Science of The Total Environment 2020, 736, https://doi.org/10.1016/j.scitotenv.2020.139185.

84. Guo, C.; Chen, Y.; Xia, W.; Qu, X.; Yuan, H.; Xie, S.; Lin, L.S. Eutrophication and heavy metal pollution patterns in the water suppling lakes of China's south-to-north water diversion project. Science of The Total Environment 2020, 711, https://doi.org/10.1016/j.scitotenv.2019.134543.

85. Barry, C.; Field, M.K. Environmental economics: an introduction. Sustainable Human Development Review, Volume 105, 1997.

86. Schiffman, S.S.; Nagle, H.T. Effect of Environmental Pollutants on Taste and Smell. Otolaryngology-Head and Neck Surgery 1992, 106, 693-700, https://doi.org/10.1177/019459989210600613.

87. Fenger, J. Urban air quality. Atmospheric Environment 1999, 33, 4877-4900, https://doi.org/10.1016/S13522310(99)00290-3.

88. Harrison, R.M.; Yin, J. Particulate matter in the atmosphere: which particle properties are important for its effects on health? Science of The Total Environment 2000, 249, 85-101, https://doi.org/10.1016/S00489697(99)00513-6.

89. Keller, E.A. Environmental Geology. 2nd edn. Charles E. Merrill Publishing, Columbus, OH, 1979; pp. 321363.

90. Bowie, S.H.U.; Thornton, I. Environmental Geochemistry and Health. Reidel, Holland, 1985, pp. 140.

91. Guo, C.; Chen, Y.; Xia, W.; Qu, X.; Yuan, H.; Xie, S.; Lin, L.-S. Eutrophication and heavy metal pollution patterns in the water suppling lakes of China's south-to-north water diversion project. Science of The Total Environment 2020, 711, https://doi.org/10.1016/j.scitotenv.2019.134543.

92. Singh Sankhla, M.; Kumar, R.; Prasad, L. Zinc Impurity in Drinking Water and Its Toxic Effect on Human Health. 2019, 17, https://doi.org/10.5958/0974-4487.2019.00015.4.

93. Karikari, A.Y.; Asmah, R.; Anku, W.W.; Amisah, S.; Agbo, N.W.; Telfer, T.C.; Ross, L.G. Heavy metal concentrations and sediment quality of a cage farm on Lake Volta, Ghana. Aquaculture Research 2020, 51, 2041-2051, https://doi.org/10.1111/are.14555.

94. Jara-Marini, M.E.; Molina-García, A.; Martínez-Durazo, Á.; Páez-Osuna, F. Trace metal trophic transference and biomagnification in a semiarid coastal lagoon impacted by agriculture and shrimp aquaculture. Environmental Science and Pollution Research 2020, 27, 5323-5336, https://doi.org/10.1007/s11356-019-06788-2.

95. Zhang, H.; Li, S.; Chen, G.; Abdulai, T.; Liu, X.; Wang, Y.; Liang, H.; Hou, J.; Huo, W.; Mao, Z.; Wang, C.; Bie, R. Ambient air pollutants aggravate association of snoring with prevalent hypertension: results from the Henan Rural Cohort. Chemosphere 2020, 256, https://doi.org/10.1016/j.chemosphere.2020.127108.

96. Kronzer, V.L.; Crowson, C.S.; Sparks, J.A.; Vassallo, R.; Davis Iii, J.M. Investigating Asthma, Allergic Disease, Passive Smoke Exposure, and Risk of Rheumatoid Arthritis. Arthritis \& Rheumatology 2019, 71, 1217-1224, https://doi.org/10.1002/art.40858.

97. Hanif, I.; Faraz Raza, S.M.; Gago-de-Santos, P.; Abbas, Q. Fossil fuels, foreign direct investment, and economic growth have triggered $\mathrm{CO} 2$ emissions in emerging Asian economies: Some empirical evidence. Energy 2019, 171, 493-501, https://doi.org/10.1016/j.energy.2019.01.011.

98. Shahbaz, M.; Gozgor, G.; Adom, P.K.; Hammoudeh, S. The technical decomposition of carbon emissions and the concerns about FDI and trade openness effects in the United States. International Economics 2019, 159, 56-73, https://doi.org/10.1016/j.inteco.2019.05.001.

99. Seror, R.; Henry, J.; Gusto, G.; Aubin, H.J.; Boutron-Ruault, M.C.; Mariette, X. Passive smoking in childhood increases the risk of developing rheumatoid arthritis. Rheumatology (Oxford) 2019, 58, 11541162, https://doi.org/10.1093/rheumatology/key219.

100. Yilmaz, B.; Terekeci, H.; Sandal, S.; Kelestimur, F. Endocrine disrupting chemicals: exposure, effects on human health, mechanism of action, models for testing and strategies for prevention. Reviews in Endocrine and Metabolic Disorders 2020, 21, 127-147, https://doi.org/10.1007/s11154-019-09521-z.

101. Song, J.; Wang, C.; Ma, A.; Zheng, H.; Zheng, W.; Hou, X.; Hu, C.; Chen, L.; Jia, W. Self-reported snoring is associated with chronic kidney disease independent of metabolic syndrome in middle-aged and elderly Chinese. Journal of Diabetes Investigation 2019, 10, 124-130, https://doi.org/10.1111/jdi.12855.

102. Afshin, A.; Sur, P.J.; Fay, K.A.; Cornaby, L.; Ferrara, G.; Salama, J.S. Health effects of dietary risks in 195 countries, 1990-2017: a systematic analysis for the global burden of disease study 2017. Lancet 2019, 393, 1958-1972, https://doi.org/10.1016/S0140-6736(19)30041-8.

103. Banzhaf, S.; Ma, L.; Timmins. C. Environmental justice: the economics of race, place, and pollution. J Econ Perspect 2019, 33, 185-208, https://doi.org/10.1007/s40572-020-00263-8.

104. Mokdad, A.H.; Mensah, G.A.; Krish, V.; Glenn, S.D.; Miller-Petrie, M.K.; Lopez, A.D.; Murray, C.J.L. Global, Regional, National, and Subnational Big Data to Inform Health Equity Research: Perspectives from the Global Burden of Disease Study 2017. Ethnicity \& disease 2019, 29, 159-172. 
105. Calas, A.; Uzu, G.; Besombes, J.-L.; Martins, J.M.F.; Redaelli, M.; Weber, S.; Charron, A.; Albinet, A.; Chevrier, F.; Brulfert, G.; Mesbah, B.; Favez, O.; Jaffrezo, J.-L. Seasonal Variations and Chemical Predictors of Oxidative Potential (OP) of Particulate Matter (PM), for Seven Urban French Sites. Atmosphere 2019, 10, https://doi.org/10.3390/atmos10110698.

106. Cesari, D.; Merico, E.; Grasso, F.M.; Decesari, S.; Belosi, F.; Manarini, F.; De Nuntiis, P.; Rinaldi, M.; Volpi, F.; Gambaro, A.; Morabito, E.; Contini, D. Source Apportionment of PM2.5 and of its Oxidative Potential in an Industrial Suburban Site in South Italy. Atmosphere 2019, 10, https://doi.org/10.3390/ATMOS10120758.

107. Yu, S.; Liu, W.; Xu, Y.; Yi, K.; Zhou, M.; Tao, S.; Liu, W. Characteristics and oxidative potential of atmospheric PM2.5 in Beijing: Source apportionment and seasonal variation. Science of The Total Environment 2019, 650, 277-287, https://doi.org/10.1016/j.scitotenv.2018.09.021.

108. Bates, J.T.; Fang, T.; Verma, V.; Zeng, L.; Weber, R.J.; Tolbert, P.E.; Abrams, J.Y.; Sarnat, S.E.; Klein, M.; Mulholland, J.A.; Russell, A.G. Review of Acellular Assays of Ambient Particulate Matter Oxidative Potential: Methods and Relationships with Composition, Sources, and Health Effects. Environmental Science \& Technology 2019, 53, 4003-4019, https://doi.org/10.1021/acs.est.8b03430.

109. Gao, D.; Godri Pollitt, K.J.; Mulholland, J.A.; Russell, A.G.; Weber, R.J. Characterization and comparison of PM2.5 oxidative potential assessed by two acellular assays. Atmos. Chem. Phys. 2020, 20, 5197-5210, https://doi.org/10.5194/acp-20-5197-2020.

110. Gao, D.; Mulholland, J.A.; Russell, A.G.; Weber, R.J. Characterization of water-insoluble oxidative potential of PM2.5 using the dithiothreitol assay. Atmospheric Environment 2020, 224, https://doi.org/10.1016/j.atmosenv.2020.117327.

111. Jiang, H.; Ahmed, C.M.S.; Zhao, Z.; Chen, J.Y.; Zhang, H.; Canchola, A.; Lin, Y.-H. Role of functional groups in reaction kinetics of dithiothreitol with secondary organic aerosols. Environmental Pollution 2020, 263, https://doi.org/10.1016/j.envpol.2020.114402.

112. Lin, M.; Yu, J.Z. Effect of metal-organic interactions on the oxidative potential of mixtures of atmospheric humic-like substances and copper/manganese as investigated by the dithiothreitol assay. Science of The Total Environment 2019, 697, https://doi.org/10.1016/j.scitotenv.2019.134012.

113. Sankhla, M. S.; Kumar, R.; Prasad, L. Distribution and Contamination Assessment of Potentially Harmful Element Chromium in Water. International Medico-Legal Reporter Journal. 2019, 2.

114. Pateriya, A.; Verma, R. K.; Sankhla, M. S.; Kumar, R. Heavy Metal Toxicity in Rice and its Effects on Human Health. Letters in Applied NanoBioScience, 2020, 10, 1, 1833-1845. https://doi.org/10.33263/LIANBS101.18331845.

115. Sonone, S. S., Jadhav, S., Sankhla, M. S., \& Kumar, R. Water Contamination by Heavy Metals and their Toxic Effect on Aquaculture and Human Health through Food Chain. Letters in Applied NanoBioScience, 2020, 10, 2, 2148 - 2166. https://doi.org/10.33263/LIANBS102.21482166.

116. Sankhla MS.; Kumar R.; Biswas A. Dynamic nature of heavy metal toxicity in water and sediments of Ayad River with climatic change. Int J Hydro. 2019, 3, 339-43, https://doi.org/10.15406/ijh.2019.03.00197.

117. Sankhla, M.S.; Kumari, M.; Nandan, M.; Kumar, R.; Agrawal, P. Heavy Metals Contamination in Water and their Hazardous Effect on Human Health-A Review. International Journal of Current Microbiology and Applied Sciences 2016, 5, 759-766, http://dx.doi.org/10.20546/ijcmas.2016.510.082.

118. Sankhla, M. S.; Kumar, R. Contaminant of Heavy Metals in Groundwater \& its Toxic Effects on Human Health \& Environment. Int. J. Environ Sci Nat Res. 2019, 18(5). https://doi.org/10.19080/IJESNR.2019.18.555996.

119. Sankhla, M. S.; Kumar, R.; Prasad, L. Variation of Chromium Concentration in Yamuna River (Delhi) Water due to Change in Temperature and Humidity. Journal of Seybold Report, 2020, 15, 9, 293-299. 